\title{
Association between IL18-607C/A and -137G/C polymorphisms and susceptibility to non- small cell lung cancer in a Chinese population
}

\author{
W.Y. Gan, H.M. Li, Y.G. Zhang, C.M. Li and Y. Wang \\ The Second Breathing and Intensive Care Ward, \\ Zhumadian City Center Hospital, Zhumadian, China \\ Corresponding author: W.Y. Gan \\ E-mail: wenyungangw@163.com \\ Genet. Mol. Res. 15 (4): gmr15048822 \\ Received May 18, 2016 \\ Accepted October 11, 2016 \\ Published December 19, 2016 \\ DOI http://dx.doi.org/10.4238/gmr15048822
}

Copyright $(C 2016$ The Authors. This is an open-access article distributed under the terms of the Creative Commons Attribution ShareAlike (CC BY-SA) 4.0 License.

\begin{abstract}
Lung cancer is one of the main causes of cancer-related mortality in males and females worldwide. A pleiotropic effect has been observed in the interleukin 18 gene (IL18); its effects include the activation of natural killer cell cytotoxicity and the promotion of the Th1 immune response through the alteration of the expression of interferon- $\gamma$ and TNF- $\alpha$ in humans. IL18 is therefore involved in the elimination of tumor cells in the human body. We recruited 357 patients with non-small cell lung cancer (NSCLC) and 414 controls to evaluate the correlation between two genetic variations (IL18-607C/A and IL18$137 \mathrm{G} / \mathrm{C}$ ) and the pathogenesis of NSCLC. We used polymerase chain reaction-restriction fragment length polymorphism to genotype IL18$607 \mathrm{C} / \mathrm{A}$ and $I L 18-137 \mathrm{G} / \mathrm{C}$. Statistical analysis revealed that individuals harboring the AA genotype of $I L 18-607 \mathrm{C} / \mathrm{A}$ had an increased risk of NSCLC compared to those harboring the CC genotype $(\mathrm{OR}=2.20$, $95 \% \mathrm{CI}=1.30-3.74)$. Individuals expressing the A allele of IL18-
\end{abstract}


607C/A had an elevated risk of developing NSCLC compared to those expressing the $\mathrm{C}$ allele $(\mathrm{OR}=1.31,95 \% \mathrm{CI}=1.06-1.62)$. In summary, our analysis shows that the $I L 18-607 \mathrm{C} / \mathrm{A}$ genetic variation is related to the risk of NSCLC, whereas the $I L 18-137 \mathrm{G} / \mathrm{C}$ variation is not. Therefore, the IL18-607C/A variation is related to the pathogenesis of NSCLC in the Chinese population studied.

Key words: Non-small cell lung cancer; IL18; IL18-607C/A; IL18-137G/C; Polymorphism

\section{INTRODUCTION}

Lung cancer is the one of the main cause of cancer-related mortality in both males and females worldwide (IARC, 2012). It is estimated that there were 1.8 million new lung cancer cases in 2012 and approximately $58 \%$ of those cases occurred in less developed regions (IARC, 2012). In China, it is estimated that 193,347 new cases of lung cancer occurred in 2012 , resulting in 175,487 deaths from the disease (IARC, 2012). The incidence and mortality rates of lung cancer in China are approximately $23.1 / 10^{5}$ and $19.7 / 10^{5}$, respectively. Nonsmall cell lung cancer (NSCLC) patients make up more than $80 \%$ of all lung cancer patients. The pathogenesis of NSCLC is poorly understood. It is well known that the etiology and pathogenesis of NSCLC involves multiple factors, such as long-term tobacco smoking, low intake of fresh fruit and vegetables, low body mass index (BMI), respiratory diseases, and longterm exposure to cooking oil fumes (Zhong et al., 1999a,b; Herbst et al., 2008; O'Callaghan et al., 2010; Goeckenjan et al., 2011; Yano et al., 2011). Moreover, certain hereditary factors are involved in its pathogenesis. Such factors include the genes that encode XPA-binding protein 2, vascular endothelial growth factor, stromal-derived factor-1, tankyrase 1, epidermal growth factor, TNF-related apoptosis-inducing ligand, and chemokine (C-C motif) ligand 2 (Krupnova et al., 2015; Luo et al., 2015; Masroor et al., 2015; Pei et al., 2015; Wang et al., 2015; Xu et al., 2015; Li et al., 2016b).

It has been reported that interleukin-18 (IL18) has a role in both anticancer and procancer (Dwivedi et al., 2015a) activity. IL18 is involved in eliminating tumor cells in the human body (Kalina et al., 2000; Marshall et al., 2006). The IL18 gene has the chromosomal locus 11q22.2-q22.3, and comprises six exons and five introns. IL18-607C/A and -137G/C are two important polymorphisms of this gene; they are located upstream of exon one and their genetic variations can affect the function of the protein (Kalina et al., 2000; Marshall et al., 2006). To date, no one has investigated the relationship between the $I L 18-137 \mathrm{G} / \mathrm{C}$ polymorphism and the risk of cancer. Therefore, in this study, we recruited 357 NSCLC patients and 414 controls with the aim of evaluating the role of IL18-607C/A (rs1946518) and -137G/C (rs187238) polymorphisms in the development of NSCLC.

\section{MATERIAL AND METHODS}

\section{Subjects}

A total of 357 patients with NSCLC and 414 controls were recruited to the current study. Between October 2013 and July 2015, the NSCLC patients were recruited from the

Genetics and Molecular Research 15 (4): gmr15048822 
Zhumadian City Center Hospital. The diagnosis of NSCLC was confirmed by pathological biopsy. The patients did not receive any chemotherapy or radiotherapy treatment prior to enrollment in the study. Patients with a history of secondary or recurrent malignant tumors and malnutrition were excluded from the study.

Between December 2013 and May 2015, 414 individuals were recruited from the outpatient clinics and health examination centers of the Zhumadian City Center Hospital. All the patients were confirmed to be free of malignant tumors, respiratory system diseases, or end-stage kidney or liver diseases.

Data on exposure to potential risk factors for NSCLC, such as gender, age, tobacco smoking, years of tobacco smoking, BMI, exposure to cooking oil fumes, and years of exposure to cooking oil fumes, were collected using an ad hoc questionnaire or from medical records. The TNM stage of the NSCLC patients was retrieved from their medical records. Tobacco use was defined as smoking at least one pack of cigarettes per week for six months. Informed consent was obtained from all NSCLC patients and controls before enrollment. The protocol for our study received approval from the ethics committee of the Zhumadian City Center Hospital. The ethical standards adopted for this study were based on the Declaration of Helsinki.

The mean ages of the NSCLC patients and controls were $64.32 \pm 7.50$ and $64.10 \pm 7.37$ years, respectively. There were $113(31.65 \%)$ female and 244 (68.35\%) male NSCLC patients, and $142(34.30 \%)$ female and $272(65.70 \%)$ male controls. Of the patients with NSCLC, 125 $(35.01 \%)$ were at stage I-II, and 232 were at stage III-IV.

\section{Genotyping}

Peripheral venous blood samples $(5 \mathrm{~mL})$ were collected from all participants and stored in tubes with $3.2 \%$ ethylenediaminetetraacetic acid. The blood samples were stored in a refrigerator at $4{ }^{\circ} \mathrm{C}$. Extraction of genomic DNA was carried out using a TIANamp Blood DNA Kit (Tiangen, Beijing, China). Genotyping of IL 18-607C/A and -137G/C was carried out by polymerase chain reaction -restriction fragment length polymorphism (PCR-RFLP). The primers, restriction enzymes, and enzyme-digested products were provided by Sangon Biotech Company and these are presented in Table 1 (all reagents were provided by Sangon Biotech Inc., Shanghai, China). The PCR regimen was as follows: one cycle of initial denaturation at $94^{\circ} \mathrm{C}$ for $5 \mathrm{~min}$; 42 cycles of $94^{\circ} \mathrm{C}$ for $30 \mathrm{~s}, 53^{\circ} \mathrm{C}$ for $30 \mathrm{~s}$, and $72^{\circ} \mathrm{C}$ for $45 \mathrm{~s}$; and a final extension at $72^{\circ} \mathrm{C}$ for $10 \mathrm{~min}$. The PCR products of $I L 18-607 \mathrm{C} / \mathrm{A}$ and $-137 \mathrm{G} / \mathrm{C}$ were digested with $\mathrm{Mse} I$ and $\mathrm{BfuCI}$ restriction enzymes at $37^{\circ} \mathrm{C}$ for $4 \mathrm{~h}$. The PCR amplification and enzyme digestion was observed on $2 \%$ agarose gel.

Table 1. Primers, restriction enzymes, and enzyme-digested products for $I L 18-607 \mathrm{C} / \mathrm{A}$ and $-137 \mathrm{G} / \mathrm{C}$.

\begin{tabular}{l|l|c|c}
\hline Genotypes & Primers (5'-3') & Restriction enzymes & Enzyme-digested products \\
\hline IL18-607C/A & TTGTAACATTGTAGGAATTACC & MseI & 137,91 and 46bp \\
& ATGTAATATCACTATTTTCATGAGA & & \\
\hline IL $18-137 \mathrm{G} / \mathrm{C}$ & $\begin{array}{l}\text { ATGCTTCTAATGGACTAAGGA } \\
\text { GTAATATCACTATTTTCATGAATT }\end{array}$ & BfuCI & 256,229 and 27bp \\
\hline
\end{tabular}

\section{Statistical analysis}

The comparison of lifestyle variables and genotype frequencies between the two investigated groups was analyzed using the chi-square test or the Student $t$-test. Using the

Genetics and Molecular Research 15 (4): gmr15048822 
Pearson chi-square test, deviation of $I L 18-607 \mathrm{C} / \mathrm{A}$ and $-137 \mathrm{G} / \mathrm{C}$ from the Hardy-Weinberg equilibrium (HWE) was determined by comparing the actual with the predicted values. The association between the $I L 18-607 \mathrm{C} / \mathrm{A}$ and $-137 \mathrm{G} / \mathrm{C}$ polymorphisms and the risk of NSCLC was examined by logistic regression analysis. The odds ratios (ORs) and $95 \%$ confidence intervals ( $95 \%$ CIs) were calculated to express the association. The IBM SPSS Statistics for Windows, Version 20.0. platform (IBM Corp., Armonk, NY, USA) was used to analyze the data.

\section{RESULTS}

General information about the NSCLC patients and controls is given in Table 2. The chi-square test revealed that the NSCLC patients had lower BMIs $\left(\chi^{2}=4.93, \mathrm{P}=0.03\right)$, were more likely to smoke $\left(\chi^{2}=11.07, \mathrm{P}=0.001\right)$, and had smoked for longer durations $\left(\chi^{2}=68.99\right.$, $\mathrm{P}<0.001)$ than the controls. However, no significant differences were observed in age $\left(\chi^{2}=\right.$ $0.54, \mathrm{P}=0.46)$ or $\operatorname{sex}\left(\chi^{2}=61, \mathrm{P}=0.44\right)$.

Table 2. General information about NSCLC patients and controls.

\begin{tabular}{|c|c|c|c|c|c|c|}
\hline Variables & Patients $(\mathrm{N}=357)$ & $\%$ & Controls $(\mathrm{N}=414)$ & $\%$ & $\chi^{2}$ value & $\mathrm{P}$ value \\
\hline \multicolumn{7}{|l|}{ Age, years } \\
\hline$<60$ & 122 & 34.17 & 152 & 36.71 & & \\
\hline$\geq 60$ & 235 & 65.83 & 262 & 63.29 & 0.54 & 0.46 \\
\hline \multicolumn{7}{|l|}{ Gender } \\
\hline Female & 113 & 31.65 & 142 & 34.30 & & \\
\hline Male & 244 & 68.35 & 272 & 65.70 & 0.61 & 0.44 \\
\hline \multicolumn{7}{|c|}{ BMI, $\mathrm{kg} / \mathrm{m}^{2}$} \\
\hline$<24$ & 248 & 69.47 & 256 & 61.84 & & \\
\hline$\geq 24$ & 109 & 30.53 & 158 & 38.16 & 4.93 & 0.03 \\
\hline \multicolumn{7}{|c|}{ Smoking status } \\
\hline No & 241 & 67.51 & 231 & 55.80 & & \\
\hline Yes & 116 & 32.49 & 183 & 44.20 & 11.07 & 0.001 \\
\hline \multicolumn{7}{|c|}{ Years of smoking } \\
\hline$<10$ & 258 & 72.27 & 176 & 42.51 & & \\
\hline$\geq 10$ & 99 & 27.73 & 238 & 57.49 & 68.99 & $<0.001$ \\
\hline \multicolumn{7}{|c|}{ TNM stage } \\
\hline I-II & 125 & 35.01 & & & & \\
\hline III-IV & 232 & 64.99 & & & & \\
\hline
\end{tabular}

NSCLC $=$ non-small cell lung cancer; $\mathrm{BMI}=$ body mass index.

The frequencies of the CC, CA, and AA genotypes of IL18-607C/A were significantly different between the NSCLC patients and the controls $\left(\chi^{2}=10.04, \mathrm{P}=0.01\right)$, whereas the frequencies of the GG, GC, and CC genotypes of IL18-137G/C did not differ significantly between the two investigated groups $\left(\chi^{2}=1.14, \mathrm{P}=0.56\right)$ (Table 3$)$. The Pearson chi-square test revealed that the genotype frequencies of $I L 18-137 \mathrm{G} / \mathrm{C}$ were in agreement with the HWE in both patients $\left(\chi^{2}=0.18, \mathrm{P}=0.67\right)$ and controls $\left(\chi^{2}=3.29, \mathrm{P}=0.07\right)$. However, the genotype frequencies of $I L 18-607 \mathrm{C} / \mathrm{A}$ were in agreement with the HWE in the patients $\left(\chi^{2}=2.71, \mathrm{P}=\right.$ $0.10)$ but not in the controls $\left(\chi^{2}=13.71, \mathrm{P}<0.001\right)$.

Logistic regression analysis revealed that individuals with the AA genotype of IL18607C/A showed an increased risk of NSCLC compared to those carrying the CC genotype $(\mathrm{OR}=2.20,95 \% \mathrm{CI}=1.30-3.74)$ (Table 4). Moreover, individuals expressing the A allele of IL18-607C/A had a higher risk of developing NSCLC than those with the $\mathrm{C}$ allele $(\mathrm{OR}=1.31$, $95 \% \mathrm{CI}=1.06-1.62)$. However, we found no significant association between the $I L 18-137 \mathrm{G} / \mathrm{C}$ genetic variation and the risk of NSCLC.

Genetics and Molecular Research 15 (4): gmr15048822 
Table 3. Genotype distributions of $I L 18-607 \mathrm{C} / \mathrm{A}$ and $-137 \mathrm{G} / \mathrm{C}$ in investigated controls.

\begin{tabular}{|c|c|c|c|c|c|c|c|c|c|c|}
\hline IL18 & Patients $(\mathrm{N}=357)$ & $\%$ & Controls $(\mathrm{N}=414)$ & $\%$ & $\chi^{2}$ value & $P$ value & \multicolumn{2}{|c|}{ HWE in patients } & \multicolumn{2}{|c|}{ HWE in controls } \\
\hline$-607 \mathrm{C} / \mathrm{A}$ & & & & & & & $\chi^{2}$ value & $\mathrm{P}$ for HWE & $\chi^{2}$ value & $P$ for $\mathrm{HWE}$ \\
\hline $\mathrm{CC}$ & 116 & 32.49 & 159 & 38.41 & & & & & & \\
\hline$\overline{\mathrm{CA}}$ & 188 & 52.66 & 222 & 53.62 & & & & & & \\
\hline $\mathrm{AA}$ & 53 & 14.85 & 33 & 7.97 & 10.04 & 0.01 & 2.71 & 0.10 & 13.71 & $<0.001$ \\
\hline$-137 \mathrm{G} / \mathrm{C}$ & & & & & & & & & & \\
\hline GG & 174 & 48.74 & 215 & 51.93 & & & & & & \\
\hline $\mathrm{GC}$ & 148 & 41.46 & 156 & 37.68 & & & & & & \\
\hline $\mathrm{CC}$ & 35 & 9.80 & 43 & 10.39 & 1.14 & 0.56 & 0.18 & 0.67 & 3.29 & 0.07 \\
\hline
\end{tabular}

HWE $=$ Hardy-Weinberg equilibrium.

Table 4. Association between $I L 18-607 \mathrm{C} / \mathrm{A}$ and $-137 \mathrm{G} / \mathrm{C}$ polymorphisms and risk of NSCLC.

\begin{tabular}{|c|c|c|c|c|c|c|}
\hline IL18 & Patients $(\mathrm{N}=357)$ & $\%$ & Controls $(\mathrm{N}=414)$ & $\%$ & Adjusted OR $(95 \% \mathrm{CI})^{1}$ & P value \\
\hline \multicolumn{7}{|c|}{$-607 \mathrm{C} / \mathrm{A}$} \\
\hline $\mathrm{CC}$ & 116 & 32.49 & 159 & 38.41 & Reference & - \\
\hline $\mathrm{CA}$ & 188 & 52.66 & 222 & 53.62 & $1.16(0.84-1.60)$ & 0.34 \\
\hline $\mathrm{AA}$ & 53 & 14.85 & 33 & 7.97 & $2.20(1.30-3.74)$ & 0.002 \\
\hline \multicolumn{7}{|c|}{ Allele } \\
\hline $\mathrm{C}$ & 420 & 58.82 & 540 & 65.22 & Reference & - \\
\hline A & 294 & 41.18 & 288 & 34.78 & $1.31(1.06-1.62)$ & 0.01 \\
\hline \multicolumn{7}{|c|}{$-137 \mathrm{G} / \mathrm{C}$} \\
\hline GG & 174 & 48.74 & 215 & 51.93 & Reference & - \\
\hline $\mathrm{GC}$ & 148 & 41.46 & 156 & 37.68 & $1.17(0.86-1.60)$ & 0.30 \\
\hline $\mathrm{CC}$ & 35 & 9.80 & 43 & 10.39 & $1.01(0.60-1.69)$ & 0.98 \\
\hline \multicolumn{7}{|l|}{ Allele } \\
\hline G & 496 & 69.47 & 586 & 70.77 & Reference & - \\
\hline $\mathrm{C}$ & 218 & 30.53 & 242 & 29.23 & $1.06(0.85-1.33)$ & 0.58 \\
\hline
\end{tabular}

${ }^{1}$ Adjusted for body mass index (BMI), smoking status, and years of smoking. NSCLC $=$ non-small cell lung cancer.

\section{DISCUSSION}

In the present study, we found that individuals carrying the AA genotype and the A allele of IL18 had an increased risk of developing NSCLC compared with those carrying the wide-type genotype. The expression of $I L 18$, which encodes an important inflammatory factor, has a critical inflammatory effect on various physiological processes in many cancers (Bao et al., 2015; Dwivedi et al., 2015b; Lu et al., 2015; Ko et al., 2016; Li et al., 2016a). Genetic polymorphisms can change the structure and quantity of the gene product, ultimately affecting its function. Genetic polymorphisms in IL18 may determine the expression and function of the protein it encodes, thereby influencing cancer susceptibility in the subjects.

Previous studies have indicated an association between IL18-607C/A and $-137 \mathrm{G} /$ $\mathrm{C}$ polymorphisms and the risk of many malignant tumors, such as esophageal cancer, gastrointestinal cancer, papillary thyroid cancer, hepatocellular carcinoma, prostate carcinoma, and oral squamous cell carcinoma (Liu et al., 2013; Singh et al., 2014; Bao et al., 2015; Chung et al., 2015; Dwivedi et al., 2015b; Li et al., 2015; Yao et al., 2015; Zhu et al., 2016). Singh et al. (2014) performed a study on 272 patients with oral squamous cell carcinoma and 185 controls, and reported that the $I L 18-137 \mathrm{G} / \mathrm{C}$ genetic variation was correlated with the progression of this cancer, but the $-607 \mathrm{C} / \mathrm{A}$ polymorphism was not. The authors of a study on 153 hepatocellular carcinoma patients and 165 healthy controls reported that the $I L 18-137 \mathrm{G} / \mathrm{C}$ polymorphism was negatively associated with the risk of hepatocellular carcinoma, but the -607C/A polymorphism was not (Bao et al., 2015). Chung et al. (2015) reported that the IL18 rs549908, rs360717, and rs187238 SNPs were positively correlated with the development

Genetics and Molecular Research 15 (4): gmr15048822 
of papillary thyroid cancer. Dwivedi et al. (2015b) found that individuals harboring the GG genotype of $I L 18$ could be diagnosed at an earlier stage than those with the CC genotype. Yao et al. (2015) examined five studies comprising 1618 patients and 1155 healthy controls, and reported that the $I L 18-607 \mathrm{C} / \mathrm{A}$ polymorphism was associated with a higher risk of esophageal cancer.

To date, only one research group has investigated the role of the IL18-607C/A genetic variation in the pathogenesis of NSCLC; Jia et al. (2016) performed a study on a Chinese population including 500 patients and 500 healthy controls, and observed a significant association between the IL18-607C/A polymorphism and the risk of NSCLC. In our study, we also observed a significant positive relationship between the $I L 18-607 \mathrm{C} / \mathrm{A}$ genetic variation and the development of NSCLC, but no association between the IL18-137G/C polymorphism and the risk of this cancer. Further studies with large-scale sample sizes are required to confirm our results. One important limitation of our study should be noted. The NSCLC patients and the controls were recruited from only one hospital in China, and IL18-607C/A did not conform with the HWE in the controls. Therefore, some selection bias could not be avoided in our study.

In conclusion, we observed that the $I L 18-607 \mathrm{C} / \mathrm{A}$ polymorphism contributes to an elevated risk of NSCLC, whereas the IL18-137G/C polymorphism does not. Therefore, the IL18-607C/A polymorphism could be a risk factor for NSCLC.

\section{Conflicts of interest}

The authors declare no conflict of interest.

\section{ACKNOWLEDGMENTS}

We would like to thank the staff at the Zhumadian City Center Hospital for their help with collecting the blood samples.

\section{REFERENCES}

Bao J, Lu Y, Deng Y, Rong C, et al. (2015). Association between IL-18 polymorphisms, serum levels, and HBV-related hepatocellular carcinoma in a Chinese population: a retrospective case-control study. Cancer Cell Int. 15: 72. http:// dx.doi.org/10.1186/s12935-015-0223-z

Chung JH, Lee YC, Eun YG, Chung JH, et al. (2015). Single nucleotide polymorphism of interleukin-18 and interleukin-18 receptor and the risk of papillary thyroid cancer. Exp. Clin. Endocrinol. Diabetes 123: 598-603. http://dx.doi. org/10.1055/s-0035-1559780

Dwivedi S, Singh S, Goel A, Khattri S, et al. (2015a). Pro-(IL-18) and Anti-(IL-10) inflammatory promoter genetic variants (intrinsic factors) with tobacco exposure (extrinsic factors) may influence susceptibility and severity of prostate carcinoma: a prospective study. Asian Pac. J. Cancer Prev. 16: 3173-3181. http://dx.doi.org/10.7314/ APJCP.2015.16.8.3173

Dwivedi S, Goel A, Mandhani A, Khattri S, et al. (2015b). Functional genetic variability at promoters of pro-(IL-18) and anti-(IL-10) inflammatory affects their mRNA expression and survival in prostate carcinoma patients: Five year follow-up study. Prostate 75: 1737-1746. http://dx.doi.org/10.1002/pros.23055

Goeckenjan G, Sitter H, Thomas M, Branscheid D, et al.; German Respiratory Society; German Cancer Society (2011). [Prevention, diagnosis, therapy, and follow-up of lung cancer. Interdisciplinary guideline of the German Respiratory Society and the German Cancer Society-abridged version]. Pneumologie 65: e51-e75. http://dx.doi. org $/ 10.1055 / \mathrm{s}-0030-1256562$

Herbst RS, Heymach JV and Lippman SM (2008). Lung cancer. N. Engl. J. Med. 359: 1367-1380. http://dx.doi. org/10.1056/NEJMra0802714

International Agency for Research on Cancer (IARC) (2012). GLOBOCAN 2012: Estimated Cancer Incidence, Mortality and Prevalence Worldwide in 2012. Available at [http://globocan.iarc.fr/Pages/fact_sheets_cancer.aspx]. Accessed August 12, 2016

Genetics and Molecular Research 15 (4): gmr15048822 
Jia Y, Zang A, Jiao S, Chen S, et al. (2016). The interleukin-18 gene promoter $-607 \mathrm{~A} / \mathrm{C}$ polymorphism contributes to non-small-cell lung cancer risk in a Chinese population. Onco Targets Ther. 9: 1715-1719. http://dx.doi.org/10.2147/ OTT.S99581

Kalina U, Ballas K, Koyama N, Kauschat D, et al. (2000). Genomic organization and regulation of the human interleukin-18 gene. Scand. J. Immunol. 52: 525-530. http://dx.doi.org/10.1046/j.1365-3083.2000.00836.x

Ko CY, Wang WL, Li CF, Jeng YM, et al. (2016). IL-18-induced interaction between IMP3 and HuR contributes to COX-2 mRNA stabilization in acute myeloid leukemia. J. Leukoc. Biol. 99: 131-141. http://dx.doi.org/10.1189/ jlb.2A0414-228RR

Li K, Wei L, Huang Y, Wu Y, et al. (2016a). Leptin promotes breast cancer cell migration and invasion via IL-18 expression and secretion. Int. J. Oncol. 48: 2479-2487.

Li X, Ren D, Li Y, Xu J, et al. (2015). Increased cancer risk associated with the -607C/A polymorphism in interleukin-18 gene promoter: an updated meta-analysis including 12,502 subjects. J. BUON 20: 902-917.

Li X, Lin F and Zhou H (2016b). Genetic polymorphism rs3760396 of the chemokine (C-C motif) ligand 2 gene (CCL2) associated with the susceptibility of lung cancer in a pathological subtype-specific manner in Han-ancestry Chinese: a case control study. BMC Cancer 16: 298. http://dx.doi.org/10.1186/s12885-016-2328-8

Liu JM, Liu JN, Wei MT, He YZ, et al. (2013). Effect of IL-18 gene promoter polymorphisms on prostate cancer occurrence and prognosis in Han Chinese population. Genet. Mol. Res. 12: 820-829. http://dx.doi.org/10.4238/2013.March.15.2

Lu Y, Bao JG, Deng Y, Rong CZ, et al. (2015). Role of IL-18 gene promoter polymorphisms, serum IL-18 levels, and risk of hepatitis B virus-related liver disease in the Guangxi Zhuang population: a retrospective case-control study. Asian Pac. J. Cancer Prev. 16: 6019-6026. http://dx.doi.org/10.7314/APJCP.2015.16.14.6019

Luo J, Xiong J, Wu J and Ye X (2015). Genetic polymorphisms and haplotypes of TRAIL gene correlate with NSCLC susceptibility in a group of Chinese patients. Int. J. Clin. Exp. Med. 8: 16223-16230.

Marshall DJ, Rudnick KA, McCarthy SG, Mateo LR, et al. (2006). Interleukin-18 enhances Th1 immunity and tumor protection of a DNA vaccine. Vaccine 24: 244-253. http://dx.doi.org/10.1016/j.vaccine.2005.07.087

Masroor M, Amit J, Javid J, Mir R, et al. (2015). Clinical implication of EGF A61G polymorphism in the risk of non small cell lung adenocarcinoma patients: a case control study. Asian Pac. J. Cancer Prev. 16: 7529-7534. http://dx.doi. org/10.7314/APJCP.2015.16.17.7529

Krupnova EV, Shapetska MN, Mikhalenko EP, Chebotaryova NV, et al. (2015). Role of vascular endothelial growth factor in non-small cell lung cancer pathogenesis. Exp. Oncol. 37: 213-217.

O'Callaghan DS, O'Donnell D, O'Connell F and O'Byrne KJ (2010). The role of inflammation in the pathogenesis of nonsmall cell lung cancer. J. Thorac. Oncol. 5: 2024-2036. http://dx.doi.org/10.1097/JTO.0b013e3181f387e4

Pei N, Cao L, Liu Y, Wu J, et al. (2015). XAB2 tagSNPs contribute to non-small cell lung cancer susceptibility in Chinese population. BMC Cancer 15: 560. http://dx.doi.org/10.1186/s12885-015-1567-4

Singh PK, Ahmad MK, Kumar V, Hussain SR, et al. (2014). Effects of interleukin-18 promoter (C607A and G137C) gene polymorphisms and their association with oral squamous cell carcinoma (OSCC) in northern India. Tumour Biol. 35: 12275-12284. http://dx.doi.org/10.1007/s13277-014-2538-0

Wang Y, Jiang W, Liu X and Zhang Y (2015). Tankyrase 1 polymorphism associated with an increased risk in developing non-small cell lung cancer in a Chinese population: a proof-of-principle study. Int. J. Clin. Exp. Pathol. 8: 1050010511.

$\mathrm{Xu}$ W, Cui R and Yu H (2015). The association between SDF-1 G801A polymorphism and non-small cell lung cancer risk in a Chinese Han population. Int. J. Clin. Exp. Med. 8: 14065-14069.

Yano T, Haro A, Shikada Y, Maruyama R, et al. (2011). Non-small cell lung cancer in never smokers as a representative 'non-smoking-associated lung cancer': epidemiology and clinical features. Int. J. Clin. Oncol. 16: 287-293. http:// dx.doi.org/10.1007/s10147-010-0160-8

Yao J, Li ZH, Li YX, Zhang R, et al. (2015). Association between the $-607 \mathrm{C}>$ A polymorphism in interleukin-18 gene promoter with gastrointestinal cancer risk: a meta-analysis. Genet. Mol. Res. 14: 16880-16887. http://dx.doi. org/10.4238/2015.December.14.15

Zhong L, Goldberg MS, Gao YT and Jin F (1999a). Lung cancer and indoor air pollution arising from Chinesestyle cooking among nonsmoking women living in Shanghai, China. Epidemiology 10: 488-494. http://dx.doi. org/10.1097/00001648-199909000-00005

Zhong L, Goldberg MS, Parent ME and Hanley JA (1999b). Risk of developing lung cancer in relation to exposure to fumes from Chinese-style cooking. Scand. J. Work Environ. Health 25: 309-316. http://dx.doi.org/10.5271/sjweh.440

Zhu J, Liu C, Teng X, Yin J, et al. (2016). Association of the interleukin-18 receptor 1 and interleukin-18 receptor accessory protein polymorphisms with the risk of esophageal cancer. Biomed. Rep. 4: 227-235.

Genetics and Molecular Research 15 (4): gmr15048822 